\title{
Poa jubata (Poaceae), a rare Balkan species, first record for the Italian flora
}

\author{
Salvatore Brullo ${ }^{1 *}$, Cristian Brullo ${ }^{1}$, Salvatore Cambria ${ }^{1}$, Gianpietro Giusso del Galdo ${ }^{1}$, \\ Pietro Minissale ${ }^{1}$, Cristina Salmeri ${ }^{2}$, Leonardo Beccarisi ${ }^{3}$, Giuseppe Veronico ${ }^{4}$, Valeria Tomaselli ${ }^{4}$ \\ ${ }^{1}$ Department of Biological, Geological and Environmental Sciences, University of Catania, A. Longo 19, 95125 Catania, \\ Italy \\ ${ }^{2}$ Department of Science and Biological, Chemical and Pharmaceutical Technologies University of Palermo, Archirafi 38, \\ 90123 Palermo, Italy \\ ${ }^{3}$ Torre Guaceto State Nature Reserve, S. Anna 6, 72012 Carovigno (BR), Italy \\ ${ }^{4}$ Italian National Research Council - Institute of Biosciences and Bioresources (CNR-IBBR), Bari, Italy
}

\begin{abstract}
Poa jubata A. Kern., an annual South-eastern European species, is reported for the first time from Italy. It is a therophyte linked to temporary ponds with soils flooded during the winter period. It is a very rare and enigmatic species, currently known only from a few localities of the Balkan Peninsula. Recently, it was surveyed in an Apulian wetland, near Brindisi, where it grows with several other annual hygrophytes. For its taxonomical isolation, it is included in a monospecific section, as $P$. sect. Jubatae. In addition to a detailed description, the chromosome complement $(2 \mathrm{n}=14)$ of this species is examined for the first time and a new iconography is provided.
\end{abstract}

Keywords: Apulia, chorology, Italy, karyology, morphology, Poa

\section{Introduction}

Poa L. is a large genus of Poaceae having a cosmopolitan distribution, with about 550 - 575 species recognized so far (Edmondson 1975, Gillespie and Soreng 2005, Soreng and Peterson 2012, Kavousi et al. 2015, Cabi et al. 2017, OrtegaOlivencia and Devesa 2018). According to molecular investigations (Gillespie and Soreng 2005, Gillespie et al. 2007, Mao and Huff 2012), Poa is a monophyletic genus, including several subgenera and sections. As concerns the Italian territory, the genus Poa is represented by 27 species (Banfi 2017, Bartolucci et al. 2018), of which only two are therophytes while the rest are perennials. The annual species are Poa annua L. and Poa infirma Kunth; the first is an allotetraploid with a hybrid origin, whose diploid parents are $P o a$ infirma and Poa supina Schrad. (Tutin 1957, Mao and Huff 2012) and is considered an invasive weed with cosmopolitan distribution, while the second is linked to wetlands and semi-natural meadows. During floristic investigations carried out in Apulia, a very peculiar and enigmatic population of an annual Poa was collected in a temporary pond close to Brindisi, not previously reported for the Italian flora (Fiori 1923, Pignatti 1982, Banfi 2017). According to Edmondson
(1980, 1985) and Cabi et al. (2017), it was possible to identify the discussed grass as Poa jubata A. Kern., a very rare species having a scattered distribution in the Balkan Peninsula. It was described by Kerner (1873) from Kotor (Cattaro) in Montenegro, while later Hackel (1898) described it as Poa grimburgii nom. illegit. from Corfu (Kerkyra) in Greece. Therefore, based on the current knowledge, Poa jubata must be treated as a new record of the Italian vascular flora.

\section{Materials and methods}

The morphological analysis was carried out on specimens collected in a wetland of Bosco Preti (Brindisi, southern Apulia), as well as on herbarium materials (available online) kept in BM, CAT, E, P, W, WU (abbreviations follow Thiers 2015). For the identification of Poa jubata the morphological descriptions and the keys provided by Hackel (1898), Edmondson (1975, 1980, 1985) and Cabi et al. (2017) were used. Morphological comparisons of Poa jubata and the most related annual Poa species are given in Tab. 1.

\footnotetext{
* Corresponding author e-mail: salvo.brullo@gmail.com
} 
Tab. 1. Distinctive features between the European annual species of Poa. Numbers in parenthesis represent rare extreme values.

\begin{tabular}{|c|c|c|c|c|}
\hline Caracters & Poa jubata & Poa annua & Poa infirma & Poa maroccana \\
\hline Habit & $\begin{array}{l}\text { stem solitary to few } \\
\text { together }\end{array}$ & $\begin{array}{l}\text { caespitose, tuffed, many- } \\
\text { stemmed }\end{array}$ & $\begin{array}{l}\text { caespitose, tuffed, } \\
\text { many-stemmed }\end{array}$ & tuffed, many-stemmed \\
\hline Stem & geniculate, erect, slender & $\begin{array}{l}\text { geniculate, erect, ascending, } \\
\text { decumbens }\end{array}$ & $\begin{array}{l}\text { geniculate, erect, } \\
\text { ascending, decumbens }\end{array}$ & $\begin{array}{l}\text { geniculate, erect, } \\
\text { ascending, decumbens }\end{array}$ \\
\hline Stem size $(\mathrm{cm})$ & $12-40(45)$ & $2-30(45)$ & $5-25(30)$ & $10-40$ \\
\hline Stem sheat covered & ca. $2 / 3$ & $2 / 3$ to almost totally & $1 / 2$ to almost totally & . \\
\hline Stem node & usually 3 & usually $1(2-3)$ & $1-2(3)$ & . \\
\hline Leaf sheat length $(\mathrm{cm})$ & $2-8.5$, fused up to $1 / 2$ & $\begin{array}{l}1-6 \text {,slightly compressed, } \\
\text { fused for } 1 / 3\end{array}$ & $\begin{array}{l}1.5-4 \text {, slightly comressed, } \\
\text { fused for } 1 / 3\end{array}$ & . \\
\hline Ligule $(\mathrm{cm})$ & $2-4(5)$ & $0.5-3(5)$ & $1-3$ & 1 \\
\hline Ligule shape & lanceolate, acute, smooth & $\begin{array}{l}\text { ovate-oblong, obtuse to } \\
\text { truncate, irregularly } \\
\text { denticulate margin }\end{array}$ & $\begin{array}{l}\text { ovate-oblong, obtuse, } \\
\text { blunt, erose }\end{array}$ & $\begin{array}{l}\text { triangular-oblong, } \\
\text { truncate }\end{array}$ \\
\hline Leaf blade size (mm) & $10-60 \times 0.6-1$ & $10-100 \times 1-5$ & $20-80 \times 1-3$ & $15-40 \times 1.5$ \\
\hline Leaf blade margin & sparsely scabrid & slightly scabrid & smooth to sparsely srabrid & slightly scabrous \\
\hline Panicle size $(\mathrm{cm})$ & $2-7$ & $1-7(10)$ & $2-10$ & up to 9 \\
\hline Panicle shape & $\begin{array}{l}\text { erect,open, elllipsoid, } \\
\text { pyramidal }\end{array}$ & $\begin{array}{l}\text { erect, open, pyramidal to } \\
\text { ovoid }\end{array}$ & $\begin{array}{l}\text { erect, congested, } \\
\text { ovoid-oblong }\end{array}$ & $\begin{array}{l}\text { triangular-ovate to } \\
\text { oblong-rhomboidal }\end{array}$ \\
\hline Panicle branches per node & $1-2(3)$ & $1-2(3)$ & $1-3$ & $1-2$ \\
\hline $\begin{array}{l}\text { Panicle primary } \\
\text { branches shape }\end{array}$ & ascendig to spreading & $\begin{array}{l}\text { spreading or reflexed, rar. } \\
\text { ascending }\end{array}$ & ascending & spreading \\
\hline Panicle branches indumentum & scabrous & glabrous & glabrous & glabrous \\
\hline Spikelet length (mm) & $3.5-6.0$ & $3-5(7)$ & $2.8-4.8$ & $5.5-6.5$ \\
\hline Spikeliet shape & broadly ovate & ovate to oblong & ovate to oblong & $\begin{array}{l}\text { narrow ovate to oblong- } \\
\text { linear }\end{array}$ \\
\hline Spikelet number florets & $4-6$ (10), compact florets & $2-6$. compact florets & (2) 4-6 spaced florets & 4 , spaced florets \\
\hline Spikelet rachilla & not exposed & usually not exposed & often exposed & usually exposed \\
\hline Glumes & subequal to unequal & unequal & unequal & unequal \\
\hline Lower glume length (mm) & $2.3-3.0$ & $1.5-2.2$ & $1-1.5$ & $1.5-2$ \\
\hline Lower glume n.ribs & 3-nerved & 1.nerved & 1-nerved & 1-nerved \\
\hline Lower glume shape & $\begin{array}{l}\text { lanceolate to lanceolate- } \\
\text { ovate }\end{array}$ & $\begin{array}{l}\text { narrowly lanceolate to } \\
\text { ovate, sickle shaped }\end{array}$ & Lanceolate & ovate-oblong \\
\hline Lower glume apex & acute & obtuse & acute to obtuse & subacute \\
\hline Upper glume length (mm) & $2.5-3.5$ & $1.5-2.5$ & $1.8-2.5$ & $1.4-2.5$ \\
\hline Upper glume $\mathrm{n}^{\circ}$ nerves & 5-nerved & 3-nerved & 3-nerved & 3-nerved \\
\hline Upper glume shape & lanceolate-ovate & lanceolate to oblanceolate & elliptic & ovate-oblong to lanceolate \\
\hline Upper glume apex & acuminate & obtuse to acute & acute to obtuse & obtuse to subacute \\
\hline Lemma length (mm) & $2.7-3.5$ & $2.2-3.5$ & $2-2.5$ & $2.5-3.7$ \\
\hline Lemma shape & obovate & broadly lanceolate to ovate & ovate to oblong & ovate \\
\hline Lemma n.ribs & $\begin{array}{l}5,3 \text { prominent, } 2 \\
\text { intermediate evanescent }\end{array}$ & 5 , all prominent & 5 , all prominent & 5 , all prominent \\
\hline Lemma keel indumentum & $\begin{array}{l}\text { densely and long villous- } \\
\text { ciliate on lower } 3 / 5\end{array}$ & $\begin{array}{l}\text { glabrous and hairy in the } \\
\text { ribs in lower } 1 / 2\end{array}$ & densely villous & densely villous \\
\hline $\begin{array}{l}\text { Lemma lateral ribs } \\
\text { indumentum }\end{array}$ & $\begin{array}{l}\text { densely and long } \\
\text { villous-ciliate on lower } 3 / 5\end{array}$ & $\begin{array}{l}\text { crisply puberulent to long } \\
\text { villous, rr. glabrous }\end{array}$ & densely villous & densely villous \\
\hline $\begin{array}{l}\text { Lemma intermediate ribs } \\
\text { inumentum }\end{array}$ & Glabrous & $\begin{array}{l}\text { crisply puberulent to long } \\
\text { villous, rr. glabrous }\end{array}$ & densely villous & densely villous \\
\hline Lemma apex & rounded & obtuse to acute & rounded & rounded to obtuse \\
\hline Palea length $(\mathrm{mm})$ & $2.4-2.6$ & $2-2.4$ & $1.7-2.3$ & . \\
\hline Palea keels indumentum & $\begin{array}{l}\text { scabrous to shortly hairy } \\
\text { and glabrous below }\end{array}$ & $\begin{array}{l}\text { short to long villous, along } \\
\text { all keels }\end{array}$ & $\begin{array}{l}\text { long villous, } \\
\text { along all keels }\end{array}$ & $\begin{array}{l}\text { long villous, along all } \\
\text { keels }\end{array}$ \\
\hline Palea flanges & $\begin{array}{l}\text { absent or very narrow and } \\
\text { appressed }\end{array}$ & $\begin{array}{l}\text { well developed and not } \\
\text { appressed }\end{array}$ & $\begin{array}{l}\text { well developed and } \\
\text { not appressed }\end{array}$ & $\begin{array}{l}\text { well developed and not } \\
\text { appressed }\end{array}$ \\
\hline Lodicules length (mm) & 0.5 & $0.45-0.5$ & 0.3 & . \\
\hline Lodicules shape & lanceolate, unlobed & $\begin{array}{l}\text { broadly lanceolate to ovate, } \\
\text { lobed }\end{array}$ & lanceolate, lobed & . \\
\hline Anther length (mm) & $0.7-1$ & $0.6-1.1(1.3)$ & $0.2-0.5$ & $0.7-1.2$ \\
\hline Caryopsis length (mm) & $1.5-1.7$ & $1.6-1.8,1.3-2.1,1.5-2.3$ & $1.1-1.4,1.5-1.9$ & $0.8-1.2$ \\
\hline Caryopsis shape & $\begin{array}{l}\text { fusiform, trigonus in cross } \\
\text { section }\end{array}$ & $\begin{array}{l}\text { ellipsoid, circular-com- } \\
\text { pressed in cross section }\end{array}$ & $\begin{array}{l}\text { ellipsoid, circular- com- } \\
\text { pressed in cross section }\end{array}$ & ovate \\
\hline
\end{tabular}


The karyological analysis was performed on mitotic plates from root-tip cells of Petri-dish germinated seeds. Roots were pre-treated for $3 \mathrm{~h}$ with a 1-bromonaphthalene saturated aqueous solution, then fixed for $12 \mathrm{~h}$ in a freshly prepared mixture of absolute ethanol with glacial acetic acid (3:1) and stored in 70\% ethanol. Treated root tips were hydrolyzed in $1 \mathrm{~N} \mathrm{HCl}$ for $8 \mathrm{~min}$ at $60^{\circ} \mathrm{C}$ and stained according to the Feulgen technique. The somatic chromosome number and complement were examined on at least 10 metaphase plates from 10 different germinated seeds. Chromosome measures and karyotype features were estimated following Brullo et al. (2014). All karyo-morphometric parameters are listed in Tab. 2. Vouchers of all examined material are kept in CAT.

\section{Results}

Poa jubata A. Kern., Oesterr. Bot. Z. 23: 6.1873 (Fig. 1)

Lectotype - Dalmatia in sylvis et subdumetis in Zuppa pr. Cattaro, May 1872, T. Plicher s.n. (WU-Kerner 0061933!), designated by Cabi et al. (2017); isotypes (WU 0061932!, BM 001217079!).
Synonyms - Poa grimburgii Hack., Oesterr. Bot. Z. 48: 12. 1898. Lectotype - In arenosis submarinis prope ostium fluminis Potamos, Corcyra, 12 April 1897, K. Grinburg s.n. (W-Hackel 1916-0014329!), designated by Cabi et al. (2017); isotypes (US! fragmentary material of type specimen ex herb. Hackel, W!).

Description (based on Apulian material) - Annual, without rhizomes, unbranched or with intravaginal branching. Culms 15-30 cm tall, erect or weakly geniculate at base, solitary or rarely in pairs, slender, flexuous, terete, glabrous, with 2-3 nodes and internodes covered by sheaths only at the base. Leaves 2-3, with sheath usually longer than the blade, throat and collar smooth and glabrous; ligule 2.5-3.5 $\mathrm{mm}$ long, glabrous, lanceolate, acute at the apex; blade 1.5$5.5 \mathrm{~cm}$ long, $0.5-1.2 \mathrm{~mm}$ wide, smooth, sparsely scabrous at the margin. Panicle $2.5-7.0 \mathrm{~cm}$ long, rhomboid to pyramidal, erect, very lax, open, with 1-3 branches per node, spreading to subpatent after flowering, sparsely to moderately scabrous in the rachis and pedicel, branches 5.-.30 $\mathrm{mm}$ long. Spikelets $3.5-5.5 \mathrm{~mm}$ long, broadly ovate, laterally compressed, green to violaceus with (3)4-6(7) crowded florets. Glumes ovate-lanceolate, subequal, shorter than ad-

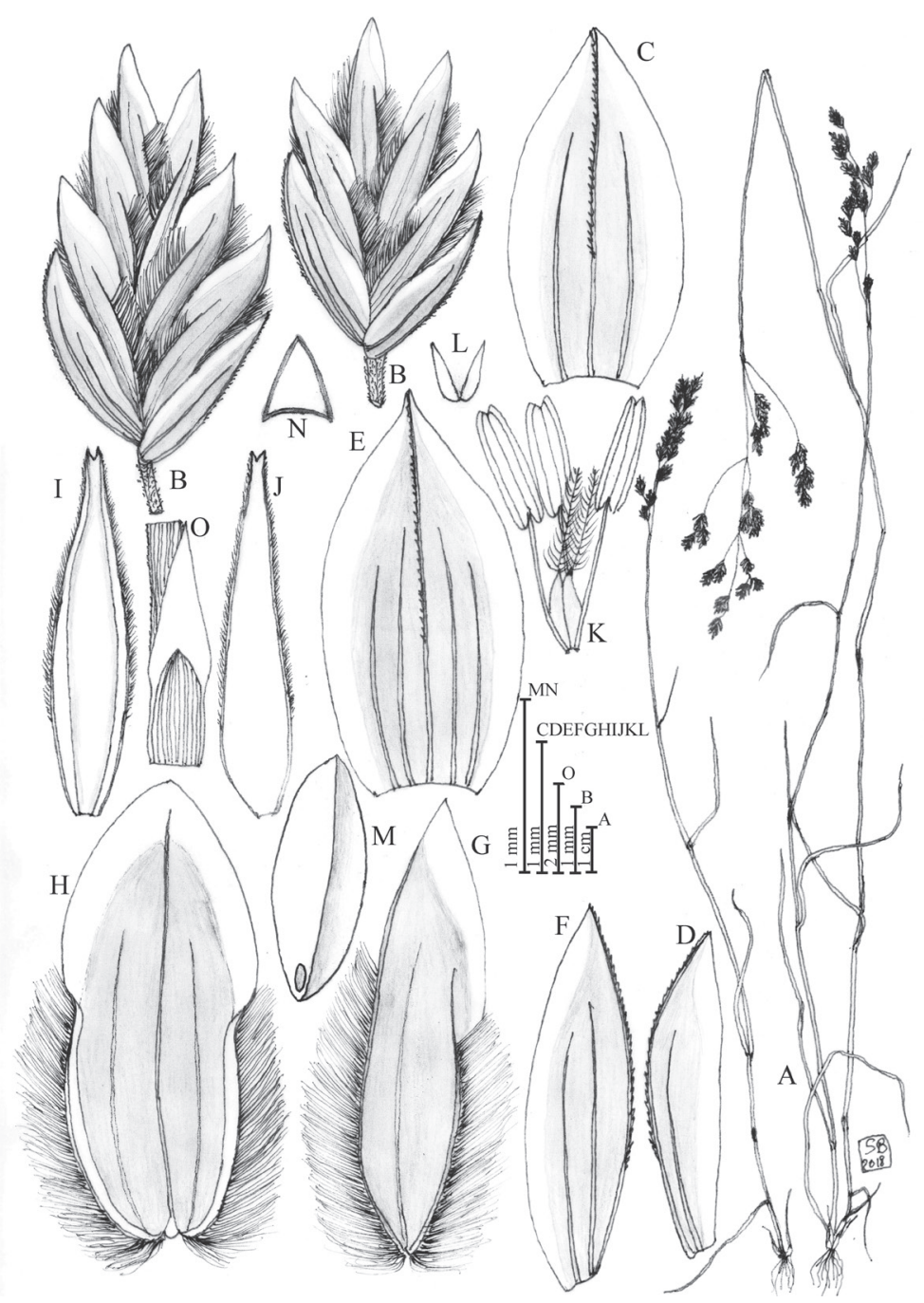

Fig. 1. Drawing of Poa jubata from living Apulian specimens: (A) habit; (B) spikelets; (C) lower glume dorsal view; (D) lower glume lateral view; (E) upper glume dorsal view; (F) upper glume lateral view; $(\mathrm{G})$ lemma lateral view; $(\mathrm{H})$ lemma ventral view; (I) palea ventral view; (J) palea dorsal view; (K) stamens and pistil; (L) lodicules; (M) caryopsis; (N) caryopsis cross section; (O) ligule. 
Tab. 2. Karyomorphometric parameters and symmetry indices of Poa jubata from Apulian samples. Mean values come from 10 metaphase plates. LA - long arm; SA - short arm; SD - standard deviation; TAL - total absolute length; TRL - total relative length; AR - arm ratio; CI - centromeric index; Type - chromosome nomenclature; TCL - total chromosome length; MCL - mean chromosome length; D-value - difference between long and short chromosome arms; DRL\% - difference of relative length; S\% - Relative length of the shortest chromosome; MAR - mean arm ratio; MCI - mean centromeric index; CVCL - coefficient of variation of chromosome length; CVCI - coefficient of variation of centromeric index, $\mathrm{m}$ - metacentric, sm - submetacentric, msm - metacentric-submetacentric.

\begin{tabular}{|c|c|c|c|c|c|c|c|}
\hline Pair & $\mathrm{LA}(\mu \mathrm{m}) \pm \mathrm{SD}$ & $\mathrm{SA}(\mu \mathrm{m}) \pm \mathrm{SD}$ & $\mathrm{TAL}(\mu \mathrm{m}) \pm \mathrm{SD}$ & $\mathrm{TRL}(\%) \pm \mathrm{SD}$ & $\mathrm{AR}$ & CI & Type \\
\hline I & $2.89 \pm 0.32$ & $2.52 \pm 0.43$ & $5.41 \pm 0.72$ & $9.94 \pm 1.18$ & 1.14 & 46.63 & $\mathrm{~m}$ \\
\hline II & $2.52 \pm 0.43$ & $2.33 \pm 0.46$ & $4.85 \pm 0.89$ & $8.90 \pm 1.41$ & 1.08 & 48.01 & $\mathrm{~m}$ \\
\hline III & $2.41 \pm 0.10$ & $1.50 \pm 0.21$ & $3.91 \pm 0.16$ & $7.21 \pm 0.37$ & 1.60 & 38.42 & $\mathrm{msm}$ \\
\hline IV & $2.26 \pm 0.13$ & $1.84 \pm 0.11$ & $4.09 \pm 0.21$ & $7.53 \pm 0.35$ & 1.23 & 44.91 & $\mathrm{~m}$ \\
\hline V & $1.82 \pm 0.20$ & $1.52 \pm 0.07$ & $3.34 \pm 0.27$ & $6.17 \pm 0.72$ & 1.20 & 45.49 & $\mathrm{~m}$ \\
\hline VI & $1.49 \pm 0.33$ & $1.30 \pm 0.27$ & $2.79 \pm 0.60$ & $5.14 \pm 1.12$ & 1.15 & 46.54 & $\mathrm{~m}$ \\
\hline VII & $1.83 \pm 0.31$ & $0.96 \pm 0.32$ & $2.79 \pm 0.63$ & $5.11 \pm 0.96$ & 1.91 & 34.41 & $\mathrm{sm}$ \\
\hline
\end{tabular}

$\mathrm{TCL}=54.37 \pm 2.95 ; \mathrm{MCL}=3.88 \pm 1 ; \mathrm{D}$-value $=6.49 ; \mathrm{DRL} \%=5.05 ; \mathrm{S} \%=49.51 ; \mathrm{MAR}=1.27$;

$\mathrm{MCI}=43.49 ;$ Stebbins' Cat. $=1 \mathrm{~B} ; \mathrm{CV}_{\mathrm{CL}}=25.72 ; \mathrm{CV}_{\mathrm{CI}}=11.20$.

jacent lemmas, distinctively veined and keeled, keel slightly scabrous above, with surfaces smooth and broadly hyaline at the margins, acute at the apex; lower glumes $2.5-3.0 \mathrm{~mm}$ long, 3-veined; upper glumes 2.8-3.2 mm long, 5-veined. Lemmas 2.7-3.5 mm long, with well distinct keel and marginal nerves, densely villous - iliate on lower $3 / 5$, with cilia $0.6-0.8 \mathrm{~mm}$ long, intermediate veins not well distinguished, glabrous, all veins not reaching the apex, which is broadly hyaline and obtuse. Palaea hyaline, 2.7-2.8 mm long, from subequal to shorter than the lemma, with keels shortly ciliolate along the upper $2 / 3$, bifid at the apex, with flanges absent or very narrow and appressed. Flowers bisexual; lodicules $0.5 \mathrm{~mm}$ long, lanceolate, unlobed, glabrous; anthers 0.7-1.0 mm long, yellow; styles $0.7-0.8 \mathrm{~mm}$ long, plumose. Caryopsis adherent to palaea, 1.3-1.5 mm long, fusiform, subtrigonous, hilum inconspicuous. Flowering time is from March to early May.

Karyology - All investigated material from Apulia showed a diploid chromosome number $2 \mathrm{n}=14$ (Fig. 2A). This is the first report of chromosome count for Poa jubata. Overall, the karyotype displays two pairs of long chromosomes, three pairs of medium length and two pairs of small chromosomes, as also confirmed by the karyomorphometric values (Tab. 2). It is prevalently characterized by metacentric chromosomes (m), except one meta-submetacentric pair (msm, arm ratio more than 1.30) and one submetacentric pair (sm). No satellited chromosomes were detected. Thus, the karyotype formula can be resumed as $2 \mathrm{n}=2 \mathrm{x}=14: 10 \mathrm{~m}$ $+2 \mathrm{msm}+2 \mathrm{sm}$ (Fig. 2B). The mean chromosome absolute length ranges from $5.43 \pm 0.7 \mu \mathrm{m}$ of the longest chromosome to $2.69 \pm 0.7 \mu \mathrm{m}$ of the smallest one, while the mean relative length varies from $9.98 \pm 1.14 \%$ to $4.92 \pm 1.1 \%$.

Habitat and ecology - In Apulia Poa jubata is very rare and occurs in temporary ponds, within cork oak woodlands on silty-sandy soils at an altitude of $50 \mathrm{~m}$ (Fig. 3). In these

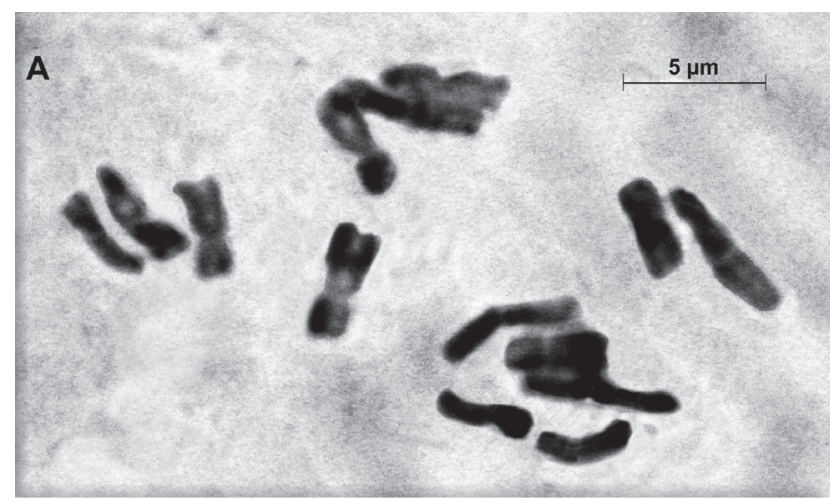

B

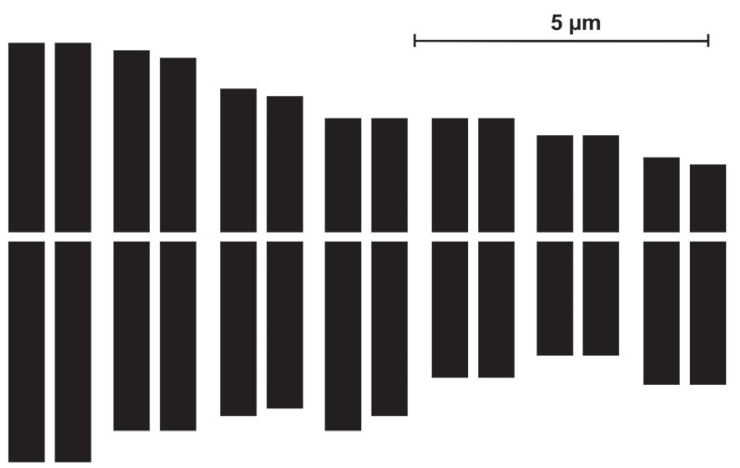

Fig. 2. Chromosome complement $(2 \mathrm{n}=2 \mathrm{x}=14)$ of Poa jubata. (A) Mitotic metaphase plate from Apulian plants; (B) Idiogram.

winter flooded wetlands, it grows together with numerous hygrophilous microphytes, such as Isoetes histrix Bory, I. sicula Tod., Centunculus minimus L., Anagallis parviflora Hoffmanns. et Link., Solenopsis laurentia (L.) C. Presl, Cicendia filiformis (L.) Delarbre, Lotus parviflorus Desf., L. angustissimus L., Polypogon subspathaceus Req., Juncus bufonius L., Ranunculus sardous Crantz, Mentha pulegium L., Gaudinia 

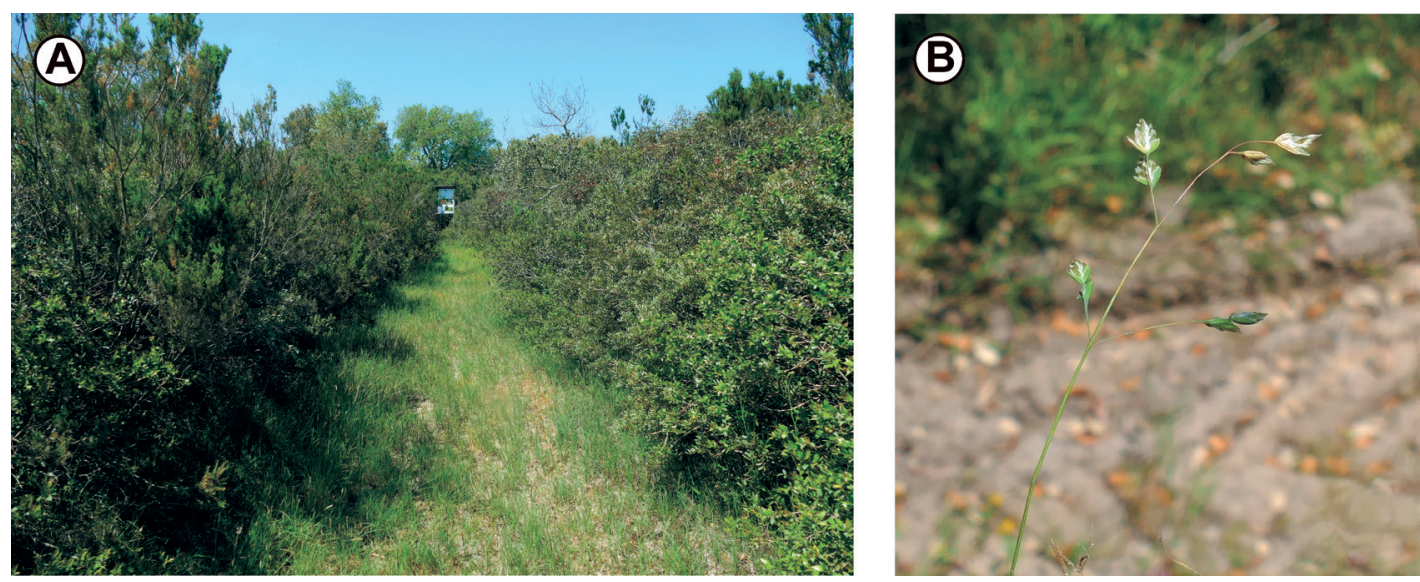

Fig. 3. Poa jubata: (A) Apulian habitat; (B) Inflorescence.

fragilis (L.) P. Beauv., etc. From the phytosociological point of view, this species is a member of a plant community belonging to the alliance Cicendio-Solenopsion laurentiae Brullo et Minissale 1998 of the Isoëto-Nanojuncetea Br.-Bl. 1935 class (see Biondi et al. 2014).

Geographical distribution - as previously highlighted, Poa jubata occurs in several East European countries, such as Montenegro, Greece, European Turkey and Bulgaria, where it is reported as a rare and scattered species (Rohlena 1913, Hayek 1933, Buschmann 1942, Edmondson 1980, 1985,
Schuler 2007, Valdés and Scholz 2009, Assyov et al. 2012, Flora Ionica Working Group 2016, Cabi et al. 2017, GBIF Secretariat, 2017), while the occurrence in Croatia and Albania is doubtful (Bedalov et al. 2000, Nikolić 2015, Vangjeli 2015, Barina et al. 2018). Overall, due to the peculiar ecological requirements and the poor numerical consistency of the populations, the real distribution range of Poa jubata is probably underestimated and would deserve further investigation. This can be also said for Italy, where the species was observed only in one stand (Fig. 4).

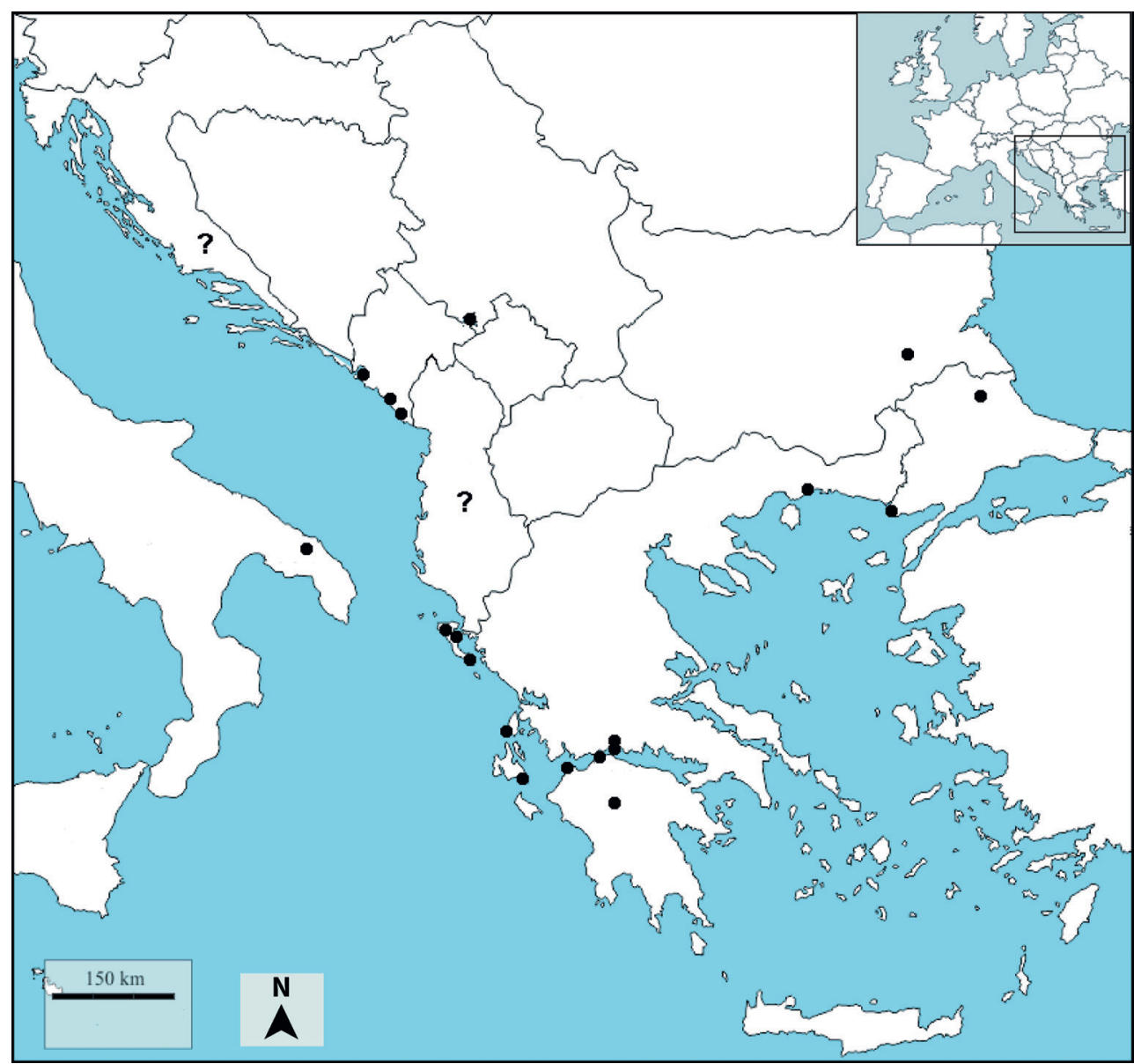

Fig. 4. General distribution map of Poa jubata based on herbarium and literature data (dots), the doubtful records are indicated with quest mark (?). 
Conservation status - From literature data (Cabi et al. 2017), Poa jubata is a very rare species with a quite scattered distribution, occurring only in wet habitats severely threatened by human activities. According to EUNIS (2012), this habitat corresponds to "Temporary lakes, ponds and pools" (code C1.6). The Apulian stand is currently little disturbed and in a good conservation status. Previously, Poa jubata was considered by Ekim et al. (2000) as Endangered (EN), while recently it was evaluated by Cabi et al. (2017) as Critically Endangered (CR) under B1ab(i,ii,iii,iv) + 2ab(i,ii,iii,iv).

Specimina visa - Greece: Korfù, Strandweisen bei Potamos, 26 April 1911, Vierhapper s.n. (WU 0096764); In arenosis submarinis prope ostium fluminis Potamos, Corcyra, 12 April 1897, K. Grinburg s.n. (W-Hackel 1916-0014329, US) Lectotypus of Poa grimbergii Hack.; Korfu, Strandweisen bei Potamo, 11 April 1911, Watzl s.n. (WU 0096765);
Potamos, Corfù, 7 April 1902, Karl Grimes v. Grinburg s.n. (WU 0096766); Corfù, 20 April 1887, Gelmi s.n. (WU 0096768); Insula Corcyra, in arenosis maritimis ad ostia fluminis "Potamos" (locus classicus), April 1901, Rosa v. Gerold 4186 (P 03370491, WU 0096767).

Montenegro: Dalmatia in sylvis et subdumetis in Zuppa pr. Cattaro, May 1872, T. Plicher s.n. (WU-Kerner 0061933) Lectotypus of Poa jubata Kern.; idem isotypes of Poa jubata (WU 0061932, BM 001217079).

European Turkey: A1(E) Kirklareli: Derenkoy to Kirklareli 14 km to Kirklareli, 25 May 1975, Baytop 317803 (E 00367534).

Italy: Apulia, Bosco Preti near Brindisi, 50 m. a.s.l., in wet depressions inside a Cork woods 23 April 2018, Beccarisi L., Brullo S., Cambria S., Tomaselli V. s.n. (CAT).

\section{Identification key to the annual species of Poa in the Euro-Mediterranean territory}

1a. Stems solitary or rarely geminate; upper glume 5-nerved; lemma long villous-ciliate on keel and marginal veins with intermediate veins evanescent; palaea scabrous to shortly hairy in the upper part of keels; caryopsis fusiform-subtrigonous.. P. jubata

1b. Stems numerous; upper glume 3-nerved; lemma sparsely hairy on keel and marginal veins with intermediate veins prominent; palaea long villous along all keels; caryopsis ellipsoid-compressed

2a. Panicle with lower branches patent or deflexed after anthesis; spikelets with crowded florets; lower glume 1.5-2.2 mm long... P. annua

2b. Panicle with lower branches erect-patent after anthesis; spikelets with rather distant florets; lower glume 1-1.5 mm

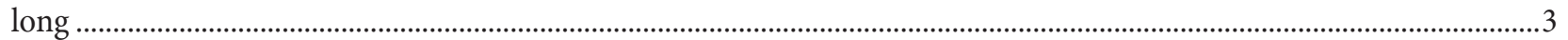

3a. Spikelets 2.8-4.8 mm long; lower glume 1-1.5 mm long; lemma 2-2.5 mm long; anthers $0.2-0.5 \mathrm{~mm}$ long... P. infirma

3b. Spikelets 5.5-6.5 mm long; lower glume 1.5-2 mm long; lemma 2.5-3.7 mm long; anthers 0.7-1.2 mm long .....

P. maroccana

\section{Discussion}

According to literature (Watson and Dallwitz 1994), the genus Poa is mainly represented by perennial species, with caespitose habit and often provided with rhizomes, stolons or bulb-like swollen vegetative shoots, while annual species are quite rare. Among the annual species the following species can be mentioned: Poa annua L. (cosmopolitan), Poa infirma Kunth (Mediterranean-Irano-Turanian), Poa maroccana Nannf. (Mediterranean), and also Poa jubata A. Kern. (South-East European), whose taxonomic position and distribution have been examined by many authors (see Nannfeldt 1938, Chrtek and Jiràsek 1962, Scholz 1968, 1993, 1996, Hernandez Cardona 1978, Edmondson 1975, 1980, 1985, Böhling and Scholz 2003, Vazquez Pardo and Garcia Alonso 2016, Gillespie et al. 2018, Ortega-Olivencia and Devesa 2018). As concerns their relationships, these species are arranged in different subgenera and sections, such as sect. $M i$ crantherae Stapf (= sect. Ochlopoa Asch. et Graebn.) of the subgen. Ochlopoa (Asch. et Graebn.) Hyl. including Poa annua, P. infirma and P. maroccana, while P. jubata, formerly considered as an incertae sedis species, has been recently referred to sect. Jubatae Cabi, Gillespie and Soreng (2005), a monotypic section whose attribution to a distinct subgenus is currently uncertain, as emphasized by Cabi et al. (2017). Indeed, Poa jubata is morphologically well differentiated from the aforementioned annual species by some relevant features, such as the mostly solitary culms, spikelets with all flowers bisexual, upper glume 5-nerved, lemma with keel and marginal veins densely and long villous-ciliate and intermediate veins evanescent and glabrous, palea with flanges absent or very narrow and appressed, caryopsis fusiform-subtrigonous (Cabi et al. 2017). All the other annual Euro-Mediterranean species of $\mathrm{Poa}$ are characterized by caespitose and many-stemmed habit, spikelets with upper flowers usually unisexual, upper glume 3-nerved, lemma with all 5 veins well distinct and more or less hairy and never long villous-ciliate, palea with flanges well developed and detached, caryopsis ellipsoid-compressed. The main morphological differences among these annual species of Poa are listed in Tab. 1. 
As far as karyology is concerned, Poa jubata shows a diploid chromosome complement with $2 \mathrm{n}=14$, not common among Poa species, which are usually high and variably polyploid (Joshi et al. 2017). Actually, this diploid complement seems shared by only a few species, such as P. infirma, also annual, as well as the perennial $P$. supina Schrad. and $P$. trivialis L.

Other annual Poa species were described from North America, such as Poa bajatensis Soreng (see Soreng and Pererson 2012) and many others from the Himalayan region (see Rajbhandari 1991, Nautiyal and Gaur 2017), but all morphologically well distinguished from those ones here examined. Actually, as highlighted by Guanghua et al. (2006), all nonEuropean annual representatives were included in various sections of another subgenus, represented by the subgen. Poa.

From the phytogeographic point of view the occurrence of Poa jubata in Apulia is difficult to explain as an accidental introduction, since it has no food or fodder interest and it is absent in agricultural habitats as a weed. It should also be noted that this species of Poa shows very limited dispersal capacity, unlike species such as Poa annua, the seeds of which are dispersed by wind, water or attached to animal fur (Holm et al. 1997). Therefore the distribution of the species could be related to paleogeographic facts such as Apulian connections with the Balkans. Recently, Royden and Faccenna (2018) stated that the Menderes-Taurus block (Western Turkey), formed the eastern extension of the Apulian continental fragment including the current Apulia, Balkan Peninsula and Anatolia at least up to 30-25 million years ago in Oligocene (Stampfli 2005). On the basis of fossil evidences, Poaceae are dated back 55-70 myr, although widespread grass-dominated ecosystems can be dated only to the early/ middle Miocene (25-15 myr) (Hodkinson 2018). Considering that Poa jubata is taxonomically quite isolated in comparison with the other Poa species, having ancestral characteristics, its origin and diffusion could be congruent to the geological time period in which the current Apulia was joined to the Balkans. An alternative explanation may refer to the glacial periods that led to a notable narrowing of the Adriatic with the emergence of the northern central part of the basin (Maselli et al. 2011), facilitating the spread of this and other amphi-Adriatic species from the Balkans to Apulia or the Italian Peninsula (Di Pietro and Wagensommer 2014, Frajman and Schönswetter 2017, Kabaš et al. 2019). Mediterranean temporary ponds and woodlands, where it grows now, could be refugial habitats of a species evolved in a more humid climate (Monegato et al. 2015).

It should be noted that the discovery of Poa jubata in Apulia can be considered as fortuitous, since it is an ecologically highly specialized hygrophyte and therefore extremely rare. It is plausible to suppose that the species in Apulia had been previously unnoticed due its inconspicuous habit and that it could also occur in similar habitats of other localities.

\section{References}

Assyov, B., Petrova, A., Dimitrov, D., Vassilev, R., 2012: Conspectus of the Bulgarian vascular flora. Ed. 4. Bulgarian Biodiversity Foundation, Sofia.

Banfi, E., 2017: Poa L. In: Pignatti, S. (ed.), Flora d'Italia 1, 521533. Edagricole, Bologna.

Barina, Z., Somogyi G., Pifcò D., Rakaj M., 2018: Checklist of vascular plants of Albania. Phytotaxa 378, 1-339.

Bartolucci, F., Peruzzi, L., Galasso, G., Albano, A., Alessandrini, A., Ardenghi, N.M.G., Astuti, G., Bacchetta, G., Ballelli, S., Banfi, E., Barberis, G., Bernardo, L., Bouvet, D., Bovio, M., Cecchi, L., Di Pietro, R., Domina, G., Fascetti, S., Fenu, G., Festi, F., Foggi, B., Gallo, L., Gottschlich, G., Gubellini, L., Iamonico, D., Iberite, M., Jiménez-Mejías, P., Lattanzi, E., Marchetti, D., Martinetto, E., Masin, R.R., Medagli, P., Passalacqua, N.G., Peccenini, S., Pennesi, R., Pierini, B., Poldini, L., Prosser, F., Raimondo, F.M., Roma-Marzio, F., Rosati, L., Santangelo, A., Scoppola, A., Scortegagna, S., Selvaggi, A., Selvi, F., Soldano, A., Stinca, A., Wagensommer, R.P., Wilhalm, T., Conti, F., 2018: An updated checklist of the vascular flora native to Italy. Plant Biosystems 152, 179-303.

Biondi, E., Blasi, C., Allegrezza, M., Anzellotti, I., Azzella, M.M., Carli, E., Casavecchia, S., Copiz, R., Del Vico, E., Facioni, L., Galdenzi, D., Gasparri, R., Lasen, C., Pesaresi, S., Poldini, L., Sburlino, G., Taffetani, F., Vagge, I., Zitti S., Zivkovic L., 2014: Plant communities of Italy: the vegetation prodrome. Plant Biosystems 148, 728-814.

Böhling, N., Scholz, H., 2003: The Gramineae (Poaceae) flora of the Southern Aegean islands (Greece). checklist, new records, internal distribution. Bericht der Institut für Landschaftsund Pflanzenökologie Universität Hohenheim, Stuttgart.
Brullo, C., Brullo, S., Fragman-Sapir, O., Giusso Del Galdo, G., Salmeri, C., 2014: Allium therinanthum (Amaryllidaceae), a new species from Israel. Phytotaxa 164, 29-40.

Buschmann, A., 1942: Zur Klärung des Fromenkreises um Poa badensis Haenke. Österreichische Botanische Zeitschrift 91, 81-130.

Cabi, E., Soreng, R.J., Gillespie, L.J., 2017: Taxonomy of Poa ju$b a t a$ and a new section of the genus (Poaceae). Turkish Journal Botany 41, 404-415.

Chrtek, J., Jiràsek, V., 1962: Contribution to the systematics of the species of the Poa L. genus, section Ochopoa (A. et G.) V. Jiràs. Preslia 34, 40-68.

Di Pietro, R., Wagensommer R.P., 2014: A new Sesleria juncifolia association from south-eastern Italy and its position in the amphi-adriatic biogeographical context. Acta Botanica Croatica $73,178-214$.

Edmondson, J.R., 1975: Taxonomic studies in the genus Poa L. (Gramineae). PhD Thesis. University of Leicester, Leicester.

Edmondson, J.R., 1980: Poa L. In: Tutin, T.G., Heywood. V.H., Burges, N.A., Moore, D.M., Valentine, D.H., Walters, S.M. (eds.), Flora Europaea, 5, 159-167. Cambridge University Press, Cambridge.

Edmondson, J.R., 1985: Poa L. In: Davis, P.H. (ed.), Flora of Turkey and the East Aegean Islands, 9, 470-486. Edinburgh University Press, Edinburgh.

Ekim, T., Koyuncu, M., Vural, M., Duman, H., Aytaç, Z., Adıgüzel, N., 2000: Turkey plant red data book (Ferns and seed plants). Turkey's Nature Protection Association, Ankara (In Turkish).

EUNIS 2012: EUNIS habitat classification 2012. Retrieved April 4, 2019 from https://eunis.eea.europa.eu/habitats/68\#legal 
Fiori, A., 1923: Nuova flora analitica d'Italia, vol. 1. M. Ricci, Firenze.

Flora Ionica Working Group, (2016 onwards): Flora Ionica - An inventory of ferns and flowering plants of the Ionian Islands (Greece). Retrieved April, 2019 from https://floraionica.univie.ac.at

Frajman, B., Schönswetter, P., 2017: Amphi-Adriatic distributions in plants revisited: Pleistocene trans-Adriatic dispersal in the Euphorbia barrelieri group (Euphorbiaceae). Botanical Journal of the Linnean Society 185, 240-252.

GBIF Secretariat, 2017: GBIF Backbone Taxonomy. Retrieved April 29, 2019 from https://doi.org/10.15468/39omei

Gillespie, L.J., Archambault, A., Soreng, R.J., 2007: Phylogeny of Poa (Poaceae) based on trnT-trnF sequence data: major clades and basal relationships. Aliso 23, 420-434.

Gillespie, L.J., Soreng, R.J., 2005: A phylogenetic analysis of the bluegrass genus Poa based on cpDNA restriction site data. Systematic Botany 30, 84-105.

Gillespie, L.J., Soreng, R.J., Cabi, E., Amin, N., 2018: Phylogeny and taxonomic synopsis of Poa subgenus Pseudopoa (including Eremopoa and Lindbergella) (Poaceae, Poeae, Poinae). PhytoKeys 111, 69-101.

Guanghua, Z., Liang, L., Soreng R.J., Glonova, M.V., 2006: 66. Poa Linnaeus. Flora of China 22, 257-309.

Hackel, E., 1898: Poa grimburgii n. s. Österreichische Botanische Zeitschrift 48, 12-14.

Hayek, A., 1933: Prodromus Florae peninsulae Balcanicae. Repertorium novarum specierum regni vegetabilis 33, 258.

Hernandez Cardona, A., 1978: Estudio monográphico de los géneros Poa y Bellardiochloa en la Pennsula Ibérica e Islas Baleares. Dissertationes botanicae 46, 1-365.

Hodkinson, T.R., 2018: Evolution and taxonomy of the grasses (Poaceae): A model family for the study of species-rich groups. Annual Plant Reviews 1, 1-39.

Holm, L.G., Doll J., Holm, E., Pancho, J.V., Herberger, J.P., 1997: World weeds: natural histories and distribution. John Wiley and Sons Inc., New York.

Joshi, A., Bushman, B.S., Pickett, B., Robbins, M.D., Staub, J.E., Johnson, P.G., 2017: Phylogenetic relationships among lowploidy species of Poa using chloroplast sequences. Genome 60, 384-392.

Kabaš, E., Niketić, M., Ćušterevska, R., Tomović, G., Vukojičić, S., Lakušić, D., 2019: Stipa crassiculmis subsp. picentina (Poaceae) new for the Balkans - a further example of amphi-Adriatic disjunction. Plant Biosystems 153, 32-38.

Kavousi, M., Assadi, M., Nejadsattari, T., 2015: Taxonomic revision of the genus Poa L. in Iran, new addition to Flora Irani$c a$, and a new identification key. Turkish Journal of Botany 39, 105-127.

Kerner, A., 1873: Zur Flora von Dalmatien, Croatien und Ungarn. Österreichische Botanische Zeitschrift 23, 6-7.

Mao, Q., Huff, D.R., 2012: The evolutionary origin of Poa annua L. Crop Sciences 52, 1910-1922.

Maselli, V., Hutton, E.W., Kettner, A.J., Syvitski, J.P.M., Trincardi, F., 2011: High-frequency sea level and sediment supply fluctuations during Termination I: An integrated sequence-stratigraphy and modeling approach from the Adriatic Sea (Central Mediterranean). Marine Geology 287, 54-70.

Monegato, G., Ravazzi, C., Culiberg, M., Pini, R., Bavec, M., Calderoni, G., Jež, J., Perego, R., 2015: Sedimentary evolution and persistence of open forests between the south-eastern Alpine fringe and the Northern Dinarides during the last glacial maximum. Palaeogeography, Palaeoclimatology, Palaeoecology 436, 23-40.
Nannfeldt, J.A., 1938: Poa maroccana Nannf. n.sp. and P. rivulorum Maire and Trabut, two more tetraploids of Sect. Ochlopoa A. and Gr., and some additional notes on Ochlopoa. Svensk Botanisk Tidskrift 32, 295-321.

Nautiyal, D.C., Gaur, R.D., 2017: Poa L., species in Uttarakhand, India and keys for their identification. Taiwania 62, 75-92.

Bedalov M., Hršak V., Hulina., Lovašen-Eberhardt Ž., Ilijanić Lj., Lukač G., Marković Lj., Mihelj D., Mitić, B., Nikolić T., Plazibat M., Regula-Bevilacqua Lj., Šegulja N., Topić J., 2000: Flora Croatica. Index Florae Croaticae. Pars 3. Natura Croatica 9.

Nikolić, T. (ed.), 2015: Flora Croatica Database. Faculty of Science, University of Zagreb. Retrieved April 4, 2019 from http://hirc.botanic.hr/fcd

Ortega-Olivencia, A., Devesa, J.A., 2018: Updated checklist of Poa in the Iberian Peninsula and Balearic islands. PhytoKeys 103, 27-60.

Pignatti, S., 1982: Flora d'Italia 3. Edagricole, Bologna.

Rajbhandari, K., 1991: A revision of the genus Poa L. (Gramineae) in the Himalaya. In: Ohba, H., Malla, S.B., (eds.), The Himalahyan plants 2, 169-261. University of Tokyo Press, Tokyo.

Rohlena, J., 1913: Fünfter Beitrag zur Flora von Montenegro. Sitzungsberichte der königlich böhmischen Gesellschaft der Wissenschaften in Prag 1912, 1-143.

Royden, L., Faccenna, C., 2018: Subduction orogeny and the late cenozoic evolution of the Mediterranean Arcs. Annual Review of Earth and Planetary Sciences 46, 261-289.

Scholz, H., 1968: Systematik und Verbreitung einiger Taxa der Gattung Poa, sektion Ochlopoa im Mittlemeegebiet. Berichte der Deutschen Botanischen Gesellschaft 81, 17-21.

Scholz, H., 1993: Festuca rivularis, Poa maroccana und Stipa monticola (Gramineae) in Griecheland. Willdenowia 23, 113-119.

Scholz, H., 1996: On annual Poa weeds, especially P. maroccana (Gramineae). Botanika Chronika 12, 15-19.

Schuler, A., 2007: Contribution to the flora of Northern and Central Greece. Willdenowia 37, 229-241.

Stampfli, G. M., 2005: Plate tectonic of the Apulia-Adria microcontinents. In: Finetti I.R. (ed.), Crop Project: Depp seismic exploration on the central Mediterranean and Italy, 747-766. Elsevier, Amsterdam.

Soreng, R.J., Peterson, P.M., 2012: Revision of Poa L. (Poaceae, Pooideae, Poeae, Poinae) in Mexico: New records, re-evaluation of $P$. ruprechtii, and two new species, $P$. palmeri and $P$. wendtii. PhytoKeys 15, 1-104.

Thiers, B., 2015: Index herbariorum: a global directory of public herbaria and associated staff. New York Botanical Garden's Virtual Herbarium. Retrieved April, 2019 from: http://sweetgum.nybg.org/ih/

Tutin, T.G., 1957: A contribution to the experimental taxonomy of Poa annua L. Watsonia 4, 1-10.

Valdés, B., Scholz. H., with contributions from Raab-Straube, E. Von, Parolly, G., 2009: Poaceae (pro parte majore). Euro+Med Plant Base - the information resource for Euro Mediterranean plant diversity. Retrieved January, 2011 from http:// www. emplantbase.org/home.html.

Vangjeli, J., 2015: Excursion flora of Albania. Koeltz Scientific Books, Königstein.

Vazquez Pardo, F.M., Garcia Alonso, D., 2016: Anotaciones corológicas y taxónomicas al género Poa L. (Gramineae) en Extremadura. Folia Botanica Extremadurensis 9, 65-72.

Watson, L., Dallwitz, M., 1994: The grass genera of the world. $\mathrm{CAB}$ International, Cambridge. 